\title{
ONLINE TEACHING LEARNING: ITS RELATIONSHIP ON PERSEVERANCE AMONG PRIVATE HIGH SCHOOL TEACHERS IN LUCBAN, QUEZON
}

\author{
Melchie Palmado Veluz \\ Faculty of Graduate Studies and Applied Research, Laguna State Polytechnic University, Main \\ Campus, Sta. Cruz, Laguna
}

Article DOI: https://doi.org/10.36713/epra7284

DOI No: 10.36713/epra7284

\begin{abstract}
As a result of outbreak and new transition of online education system, the researcher will find-out and determine the relationship of online teaching learning to teacher's perseverance. To analyze the difficulties and solution on the new normal of education. To be aware to the enhancement and improvement of the online teaching learning. Specifically, it sought to answer the following questions; What is the level of online teaching learning among private high school teachers in Lucban, Quezon in terms of; instructional strategies, challenges, support; What is the level of teachers' perseverance among private high school in Lucban, Quezon in terms of; adaptability of virtual technology, learning interest, motivation; and Is there a significant relationship between online teaching learning and teachers' perseverance among private high school in Lucban, Quezon?

The research design used in this study was descriptive survey method of research. The population of the study was made up of the total population of Private High School Teachers in Lucban, Quezon. Online survey questionnaire were the main instruments used to gather information needed for descriptive presentation of data, weighted mean and standard deviation were used, for the hypothesis presentation of data, the researcher used Pearson r Correlation.

Based on the data, it is shown that there is "a partial relationship between online teaching learning and teacher's perseverance among private high school in Lucban, Quezon" at 0.05 level of significance. It showed that the null hypothesis stating that "There is no significant relationship between online teaching learning and teachers' perseverance among private high school in Lucban, Quezon" was partially rejected, it could be inferred that there was "significant relationship between them".

Based on the findings and conclusions made, the following recommendations are given; Triangular efforts to be made by the school principal, teachers and students in upgrading the virtual skills of teachers as an intervention perspective as an action plan for them as well for the benefit of the students; Continuous enhancement of training/webinar program on online teaching learning may be conducted for sustainability of the skills of teachers;

Continuous support of the administration financially to better equip skills and knowledge for smooth implementation of online teaching learning; and follow - up studies of similar nature and wiser magnitude must made in other areas in Quezon in order to countercheck the veracity of the findings in this study.
\end{abstract}

\section{INTRODUCTION}

As of the outbreak across the world, almost all aspects of our life were changed and were affected. As human being, we never expected such things and not prepared at the same time. Educational system is not exempted for these changes. Students, parents and teachers were critically hit by the unprecedented changes. In order to implement the requirements of no suspension of learning consequently no suspension of teaching. The educational institutions organize the largest elearning and online instructions. Therefore, all of the courses are implemented online without enough preparation for both teachers and students. It is a big challenge for everyone especially for the teachers, who get to use the lecture and discussion on face-toface basis of learning. 
Having enough knowledge with the changes in online teaching and learning process, teachers tend to adapt and adjust to the new systems of education. Online teachers play an important role in the success or failure of the online teaching and learning method. They must be technically educated and well trained in order to enhance the quality of online teaching and learning. Teachers should possess flexibility towards the changes that they encountered through online teaching learning, and how to respond rightfully to the demand of the new normal education.

In this field, the researcher intended to determine the relationship of the online teaching learning and the teachers' perseverance. If there is a correlation to the given variables.

The reason why the researcher focuses on the "Online teaching learning: its relationship on perseverance among private high school teachers in Lucban, Quezon", to analyze the range of online teaching learning through instructional strategies. Online teaching learning emphasizes internet-based courses that can offered synchronous and asynchronous method, and to some subject matter as to design into display on LMS, Moodle, email systems, and blogs in online discussions and other online platform. The challenges that the online teachers encountered usually technical glitches, condition of the students, parents, administrators and financial availability to support the online teaching learning process. Online teachers' perseverance can be affected, that's why the researcher wants to know the relationship of online teaching learning and how can they adapt to virtual technology, and to quantity the teacher's willingness to learn the new system and how motivated in doing the new online system.

Through this study, the researcher will find out and determine the relationship of online teaching learning to the teachers' perseverance. To be aware to the enhancement and improvement of the online teaching learning.

\section{MATERIALS AND METHODS}

The research design used in this study was descriptive survey method of research. It aimed to determine the relationship of the online teaching learning and the teachers' perseverance among private high school teachers in Lucban, Quezon.

The population of the study was made up of the total population of Private High School Teachers in Lucban, Quezon. Private High School Teachers were used for the study because the researcher believed that these group of people are one of the affected on the online teaching learning.

Online survey questionnaire were the main instruments used to gather information needed for descriptive presentation of data, weighted mean and standard deviation were used. For the hypothesis presentation of data, Pearson $r$ Correlation, to measure the strength of association between two variables and the direction of the relationship.

\section{RESULTS AND DISCUSSION}

Table 1 Level of online teaching learning among private high school teachers in terms of Instructional Strategies. To a very high interpretation, the teachers used photos, charts, models, videos, etc. during online lectures for making learning more joyful and effective for the students with $(M=3.73$, $S D=0.45)$ and had the preference to use google classroom, google forms, zoom, worksheets, WhatsApp, YouTube in delivering learning material with $(M=3.55, S D=0.50)$. Although also observed to a high interpretation, the item with the lowest rating was the teacher gave students online projects instead of book-based objectives question-answer with $(M=3.09, S D=0.64)$.

The overall mean of 3.48 , standard deviation of 0.560 , indicated the level of online teaching learning among private high school teachers in terms of instructional strategies had a remark of strongly agree and verbally interpreted as very high.

The finding showed that the online teaching learning among private high school teachers in terms of instructional strategies using instructional media, method, step, teaching time, learning tools, students' assessment is very evident.

As reflected on the finding, it means that the private high school teachers in Lucban, Quezon are ready to the new instructional method, step, teaching time, learning tools and student's assessment.

Table 2, level of online teaching learning among private high school teachers in terms of Challenges. To a very high interpretation, the teachers prefered to have a training, webinar and faculty professional development with $(M=3.55, S D$ $=0.50$ ) and have the sufficient computer knowledge and IT skills to conduct online lectures with $(M=$ $3.28, S D=0.70$ ). Although also it was observed to a high interpretation, the item with the lowest rating was the teacher had the possibility of an obstacles to attention from other family members during online lectures and their online classroom gives students sense of autonomy as it intrinsically motivates them with $(M=3.16, S D=0.78,0.51)$.

The overall mean of 3.27 , standard deviation of 0.665 , indicated the level of online teaching learning among private high school teachers in terms of challenges have a remark of strongly agree and verbally interpreted as very high.

The finding shows that the online teaching learning among private high school teachers in terms of challenges like technical barriers, student participation, students' conditioning, and experience on teaching is very apparent.

It means that they clearly understood that online teaching learning is a big challenge for the 


\section{EPRA International Journal of Research and Development (IJRD)}

private high school teachers, these include, time management, suitability of online teaching technology platforms, issue of conducive environment, self-motivation, virtual communication and consultation.

Table 3. Level of online teaching learning among private high school teachers in terms of Support. To a very high interpretation, the teachers are requiring to attend webinar and professional development with $(M=3.61, S D=0.49)$ and the School Principal gives encouraging feedback and comments to motivate the teachers to teach online classes with $(M=3.48, S D=0.62)$. Although also observed to a high interpretation, the item with the lowest rating was the administration allots funds for the teachers for their online classes' expenses with $(M=3.25, S D=0.71)$.

The overall mean of 3.43, standard deviation of 0.599 , indicate the level of online teaching learning among private high school teachers in terms of support have a remark of strongly agree and verbally interpreted as very high.

The finding shows that the online teaching learning among private high school teachers in terms of support from the Administrator, School Principal, Co-teachers, Parents, Student, and Administration is well manifested.

As reflected on the finding, that the teachers believe that they proved online teaching learning were supported by the school, school administration, school principals, co-worker, students and parents.

Table 4 shows the rank the online teaching learning among private high school teachers in terms of instructional strategies have the highest (OM= $3.48, S D=0.560$ ) and verbally interpreted as very high. Followed by the Support with $(O M=3.43, S D$ $=0.599$ ) and verbally interpreted as very high. While the Challenges have the lowest $(O M=3.27, S D=$ 0.665 ) and verbally interpreted as very high also.

The total mean of 3.39 , standard deviation of 0.616 , indicate that the online teaching learning among private high school teachers is verbally interpreted as very high.

The finding shows that the online teaching learning among private high school teachers in Lucban, Quezon is well exhibited.

Table 5. Level of teachers' perseverance among private high school in terms of Adaptability of Virtual Technology. To a very high interpretation, the teacher easily performs file management tasks on the computer such as copying, moving, renaming and deleting files on folders with $(M=3.48, S D=0.56)$ and uses variety of online teaching strategies to help students to learn with $(M=3.44, S D=0.66)$. Although also observed to a very high interpretation, the item with the lowest rating was the teacher knows the different kinds of online platform that can use on online classes with $(M=3.31, S D=0.59)$.
The overall mean of 3.38 , standard deviation of 0.607 , indicate the level of teachers' perseverance among private high school in terms of adaptability of virtual technology have a remark of strongly agree and verbally interpreted as very high.

The finding shows that the teachers' perseverance among private high school in terms of adaptability of virtual technology is very obvious.

It means that the private high school teachers can easily adapt to the new form of online platform of education system.

Table 6. Level of teachers' perseverance among private high school in terms of Learning Interest. To a very high interpretation, the teacher collaborates with other teachers regarding instructional strategies, method and step with $(M=$ 3.61, $S D=0.49$ ) and attends online training about online teaching and learning methodology, management, knowledge, skills and delivery with $(M$ $=3.55, S D=0.50$ ). Although also observed to a high interpretation, the item with the lowest rating was the teacher feels well-equipped and well-trained on the use of tools for online teaching learning with $(M=$ 3.19, $S D=0.66$ ).

The overall mean of 3.45 , standard deviation of 0.563 , indicate the level of teachers' perseverance among private high school in terms of learning interest have a remark of strongly agree and verbally interpreted as very high.

The finding shows that the teachers' perseverance among private high school in terms of learning interest is well demonstrated.

As reflected on the finding, the teachers proved that they are interested to learn new knowledge and skills about online teaching learning.

Table 7. Level of teachers' perseverance among private high school in terms of Motivation. To a very high interpretation, the teacher has the access to and opportunity to use technology/gadgets in the school with $(M=3.52, S D=0.50)$ and innovative online teaching learning with $(M=3.42, S D=0.50)$. Although also observed to a high interpretation, the item with the lowest rating was the teacher give the extra financial incentives, reduced number of online teaching, additional training hours and additional ICT equipment for the online classes with $(M=3.13, S D$ $=0.75$ ).

The overall mean of 3.36, standard deviation of 0.603 , indicate the level of teachers' perseverance among private high school in terms of motivation have a remark of strongly agree and verbally interpreted as very high.

The finding shows that the teachers' perseverance among private high school in terms of motivation is well established.

Teachers in private high schools are well motivated, it means that no matter what they 


\section{EPRA International Journal of Research and Development (IJRD)}

encountered difficulties in online teaching learning they are being motivated to teach the students.

Table 8 shows that the teachers' perseverance among private high school teachers in terms of Learning Interest have the highest (OM= $3.45, S D=0.563$ ) and verbally interpreted as very high. Followed by the Adaptability of Virtual Technology with $(O M=3.38, S D=0.607)$ and verbally interpreted as very high. While the Motivation have the lowest $(O M=3.36, S D=0.603)$ and verbally interpreted as very high also.

The total mean of 3.40 , standard deviation of 0.592 , indicate that the teachers' perseverance among private high school teachers is verbally interpreted as very high.

The finding shows that the teachers' perseverance among private high school teachers in Lucban, Quezon is well revealed.

It shows that they are persistence in doing something despite of difficulties and failures.

Table 9 shows the significant relationship between online teaching learning and teachers' perseverance among private high school in Lucban, Quezon

The Online Teaching Learning that has relationship to the Teachers' Perseverance includes Adaptability of Virtual Technology, Learning Interest and Motivation.

The Instructional Strategies, Challenges and Support for Adaptability of Virtual Technology, Learning Interest and Motivation are significant at probability level. This means that the online teaching learning has a slight correlation or definite but small relationship to high correlation or marked relationship to the teachers' perseverance among private high

Based on the data, it is shown that there was "a partial relationship between online teaching learning and teachers' perseverance among private high school in Lucban, Quezon" at 0.05 level of significance. It shows that the null hypothesis stating that "There is no significant relationship between online teaching learning and teachers' perseverance among private high school in Lucban, Quezon" was partially rejected, it could be inferred that there is "significant" relationship between them.

\section{CONCLUSIONS}

It was therefore concluded that there is "a partial" relationship between online teaching learning and teachers' perseverance among private high school teachers in Lucban, Quezon at 0.05 level of significance. It showed that the null hypothesis stating that "There is no significant relationship between online teaching learning and teachers' perseverance among private high school teachers in Lucban, Quezon" was partially rejected, it could be inferred that there was "significant" relationship between them.

\section{Recommendations}

Based on the findings and conclusions made, the following recommendations are given;

1. Triangular efforts to be made by the school principal, teachers and students in upgrading the virtual skills of teachers as an intervention perspective as an action plan for them as well for the benefit of the students.

2. Continuous enhancement of training/webinar program on online teaching learning may be conducted for sustainability of the skills of teachers.

3. Continuous support of the administration financially to better equip skills and knowledge for smooth implementation of online teaching learning.

4. Follow - up studies of similar nature and wiser magnitude must made in other areas in Quezon in order to countercheck the veracity of the findings in this study.

\section{Acknowledgement}

To Almighty God Father, thank you for all the guidance and help, for giving knowledge and wisdom to complete and finish this research study successfully.

MARIO R. BRIONES, Ed. D University President of Laguna State Polytechnic University for providing quality graduates in the field of education.

A/P JOSEPHINE H. CONSEBIDO, LPT, Rpm Research Adviser for giving me the opportunity to do research and providing invaluable guidance throughout this research.

FLORHAIDA V. PAMATMAT, Ed. D Dean College of Teacher Education for kindness and words of encouragement.

ALBINA S. BUNYI, Ed. D Subject Specialist for inspiring and motivating to finish this research study.

HAROLD V. ORIGINES, Ed. D Statistician for valuable time and effort in sharing his expertise in Statistics.

JULIE ROSE P. MENDOZA, Ed. D Technical Expert providing valuable guidance throughout this research.

VIOLETA RANA, Language Critic for valuable time and effort in sharing her expertise in editing the manuscript.

Abigail Viar RGC, External Panelist for sharing her knowledge throughout this research.

Benjamin Arjona, Ed. D External Statistician for valuable effort and time to taught the methodology to carry out the research and to present the research works as clearly as possible. 


\section{EPRA International Journal of Research and Development (IJRD)}

To all School Principals, to make this study possible namely: Mrs. Lydia R. Dean, Lucban Academy; Mrs. Fe S. Oblea, Banahaw View Academy; Rev. Msgr. Antonio L. Obeña, Casa Del Niño Jesus de Lucban; and Antonio C. Lozano, Lucban Christian School.

To all private high school teachers in Lucban, Quezon for their kindness and genuine support throughout this research work.

Mr. and Mrs. Raymundo and Silveria Palmado, her parents for the unconditional love and support. For preparing and educating to be the best person. Mostly to her husband Ric A. Veluz, for the loved, support and understanding and her sons/daughter; Christian Paul, Christine Rica and Christmel Ric for continuing believing and loving unconditionally.

To Doña Consuelo Eleazar Perez, Dra. Eliza Mei P. Francisco and Dr. Lionel D. Francisco, Board of Trustees and President of Lucban Academy for the genuine support and scholarship to complete this Masteral Degree.

Finally, thank you to all the people, friends, and classmates who supported to complete this research study work directly and indirectly.

\section{REFERENCES}

1. Alea, Lapada Aris, Fabrea, Miguel Frosyl, Robledo, Dave Arthur R. and Faroogi, Alam Zeba, June 2020. Teachers' COVID 19 Awareness, distance learning education experiences and perceptions towards institutional readiness and challenges. International Journal of Learning, Teaching and Educational Research, Vol. 19, No. 6, pp. 127-144. Retrieved from https://doi.org/10.268031.

2. Ahmad, Saghir Ch., Dr. Batrol, Ayesha and Bashir, Majid, 2020. Pandemic COVID-19 Source of Online Digital Learning Platform for Learning Management and Psychological Dynamics Disorders of Students. Hamdardislamicus, Vol. 43, No. 3, pp. 101-116. Retrieved https://hamdardfoundation.org/hamdardislamicus.

3. Bernet, Sue, Priest, Ann-Marie and Macpherson, Colin, 1999. Learning about Online Learning: An approach to staff development for University Teachers. Australian Journal of Educational Technology, Vol. 15, No. 3. Retrieved from https://doi.org/10.14742/ajet.1858.

4. Chang, Chiu-Lan and Fang, Ming, 2020. Elearning and Online Instructions of Higher Education during the 2019 Novel Coronavirus Diseases (COVID-19) Epidemic. Journal of Physics: Conference Series 1574 (2020). Retrieved from doilo.1088/17426596/1574/012166.

5. Chung, E., Noor, N.M., \& Vloreen Nity Matthew, 2020. Are you ready? Assessment of Online
Learning Readiness among University Students. International Journal of Academic Research in Progressive and Development, Vol. 9, No. 1, pp. 301-317.

6. Chung, Ellen, Subramaniam, Geetha and Dass, Laura Christ, July 2020. Online Learning Readiness among University Students in Malaysia Amidst COVID-19. Asian Journal of University Education (AJUE), Vol. 16, No. 2. Retrieved from https://doi.org/10.24191/ajue.vl6;2.10294.

7. Cuthrell, Kristen, Lyon, Anna, Dec 2007. Instructional Strategies: What do Online Students Prefer? MERLOT Journal of Online Learning and Teaching, Vol. 3, No. 4.

8. Cutri, Ramona Maile, Mena, Juanjo and Whiting, Erin Feinauer, Sept. 2020. Faculty Readiness for Online Crisis Teaching: Transitioning to online Teaching during the COVID-19 Pandemic. European Journal of Teacher Education, Vo. 43, No. 3, pp. 523-541. Retrieved from https://doi.org/10.1080/02619768,2020.1815702.

9. Darling-hammond, L., \& Rothman, R., 2015. Teaching in the flat world: Learning from higperforming systems. New York, NY: Teachers College Press.

10. Malaysian Ministry of Higher Education, 2020. Press Release by the Malaysian Ministry of Higher Education. Retrieved from https://www.nst.com.my/education/2020/06/5995 86/overseas.dream-put-hold.

11. Nafisah, S. B., Alamery, A. H., Al Nasfesa, A., Aleid, B., \& Brazanji, N. A., 2018. School Closure during Novel Influenza: A systematic review. Journal of Infection and Public Health, Vol. 11, No. 5, pp. 657-661.

12. Nambiar, Deepika, 2020. The Impact of Online Learning during COVID-19: Student's and Teachers's Perspective. The International Journal of Indian Psychology, ISSN 2348-5396 (online)/ISSN: 2349-3429 (print), Vol. 8, Issue 2, April-June, 2020. Retrieved from http://www.ijip.in.

13. O'neil, Harold F., 2006. Web-Based Learning: Theory, Research, Practice. Lawrence Erlbaun Associate, Inc. Publishers, 10 Industrial Avenue Mahevah, New Jersey.

14. Perez, H.S, Fernandez, S.R, \& Braojos, C.G, 2010. Methodologies that optimize Communication in virtual learning environment. Communicate: Ibero-American Scientific Journal of Communication and Education, Vol. 17, No. 34, pp. 163-171.

15. Phan, Than Thi Ngoc and Dang, Ly Thi Thao, 2017. Teacher Readiness for Online Teaching: A Critical Review. Ijodel, Vol. 3, No. 1.

16. Radford, A.W., \& Weko, T., 2011. Learning at a distant: Undergraduate Enrollment in Distance Education Courses and Degree Program. (NCE 2012-154), Washington, D. C. National Center for Education Statistics.

17. Rasmitadila, R., Rachmadtullah R., Rusi Rusmiati, A., and Samsudin, A., 2020. The Perceptions of Primary School Teachers of 
Online Learning during the Covid-19 Pandemic Period: A Case Study in Indonesia. Journal of Ethnic and Cultural Studies, Vol. 7, No. 2, pp. 90-109.

18. Republic Act. No. 10650, July 28, 2014. An Act Expanding Access to Educational Service by Institutionalizing Open Distance Learning in level of Tertiary Education and Appropriating Funds. www.officialgazette.gov.ph.

19. Reyes, M.R., Brackett, M.A., White, M., \& Salovey, P., 2012. Classroom Emotional Climate, Student Engagement and Academic Achievement. Journal of Educational Psychology, Vol. 104, No. 3, pp. 700-712.

20. So, Simon, 2009. The Development of a SMS Based Technology and Learning System. Journal of Education Technology Development and Exchange (JETDE), Vol. 2, Iss. 1, Article 8, pp. 99-112.

21. Ventayin, R.J., 2018. Teachers' Readiness in Online Teaching Environment: A case of Department of Education Teachers. Journal of Education, Management and social Studies, Vol. 2, No. 1. Retrieved from www.psurj.org/jemss.

22. Yang, Y., \& Cornelius, L.F, 2004. Students, Perceptions towards the quality of Online Education: A qualitative approach. Association for Educational Communications and Technology, Vol. 27, pp. 861-877.

23. Zweig, J., Stafford, E., 2016. Training for Online Teachers to Support Student Success: Themes from a Survey Administered to Teachers in Four Online Learning Programs. Journal of Online Learning Research, Vol. 2, No. 4, pp. 399-418. 